\title{
Sustainable Development Goals: A Powerful Framework for Embedding Ethics, CSR, and Sustainability in Management Education
}

\author{
Dolors Setó-Pamies and Eleni Papaoikonomou * \\ Department of Business Management, Faculty of Business and Economics, Universitat Rovira i Virgili, \\ 43003 Tarragona, Spain; dolors.seto@urv.cat \\ * Correspondence: eleni.papaoikonomou@urv.cat; Tel.: +34-977759882
}

Received: 14 February 2020; Accepted: 25 February 2020; Published: 27 February 2020

check for updates

\begin{abstract}
In this editorial we are delighted to present the four papers included in this special issue. Each of them tackles different issues with important academic and managerial implications. Then, we will discuss the Sustainable Development Goals (SDGs) and the potential they represent for higher education institutions and management education, in particular. One of the most important challenges in this field will be how to introduce SDGs in management education, an area of interest for practitioners and academics.
\end{abstract}

Keywords: sustainable development goals; management education; management curricula; sustainability; ethics; corporate social responsibility

\section{Introduction}

Management education should offer the necessary knowledge and skills for future business leaders, so that they can contribute in giving responses to the world's most pressing challenges, such as climate change, water scarcity, poverty, and social inequality, which will transform the world we live in. To this end, as argued in previous literature, introducing ethics, corporate social responsibility (CSR), and sustainability (ECSRS) into management education could play an important role in addressing the complex social, economic, and environmental challenges our society faces, while repairing the tarnished social contract between business and society [1,2].

Some efforts have already been made by universities and business schools to integrate business ethics, corporate social responsibility, and sustainability into management education [3-5]. Now more than ever before-in the context of the 2030 Agenda for Sustainable Development-academic institutions are asked to assume responsibility and lead the thoughts and actions on pressing social and environmental issues.

In this Special Issue we see how sustainability has been approached until now in management education. We are delighted to present the four papers finally included in this issue. The first paper "How Does Reciprocity Affect Undergraduate Student Orientation Towards Stakeholders?" by José Luis Godos-Diez, Roberto Fernández-Gago, and Laura Cabeza-García adopts an individual level of analysis showing how the reciprocal and non-reciprocal components in decision making affect the stance towards the company's stakeholders. One important implication of their study is that management education should adopt a more humanistic perspective. The second paper "Are Corporate Social Responsibility Courses Effective? A Longitudinal and Gender-Based Analysis in Undergraduate Students" by Pablo Ruiz-Palomino, Ricardo Martínez-Cañas, and Pedro Jiménez-Estévez offers empirical evidence regarding the effectiveness of CSR courses and the role of gender in this relationship. In a similar vein with the first article, the authors suggest that a human rooted conception of business 
should be promoted in management education; they point out the need for experiential and service learning methodologies so that such courses are effective both for male and female students. The third paper "Ethics, Responsibility, and Sustainability in MBAs. Understanding the Motivations for the Incorporation of ERS in Less Traditional Markets" by Gaston Fornes, Abel Monfort, Camelia Ilie, Chung Kwon Koo, and Guillermo Cardoza presents an in-depth analysis of three case studies of MBAs based in Latin America, Asia, and Southern Europe and the different motivations/predictors for the inclusion of ethics, responsibility, and sustainability in learning activities. Their study adopts a distinct perspective by analyzing MBA education in regions with different histories, legacies, and trajectories than the Global North. Finally, the fourth paper "Ranking of Sustainability Journals Using the Author Affiliation Index and Comparison to Other Journal Metrics" by Matias Ginieis and Xiaoni Li focuses on a different aspect by examining the issue of evaluating research productivity in management schools offering sustainability-related programs. Additionally, their study suggests an alternative quality measure for academic journals.

\section{A New Context: SDGs}

In September 2015, world leaders at the United Nations unanimously adopted a new global development agenda, Transforming Our World: The 2030 Agenda for Sustainable Development, one of the most ambitious and important global agreements in recent history. The agenda, which came into effect on 1 January 2016 with the 17 Sustainable Development Goals (SDGs) at its core, is a guide to tackle the world's most pressing challenges including ending poverty and bringing economic prosperity, social inclusion, environmental sustainability, and peace to all countries and all people by 2030. There is already a strong interest in, and response to, the SDGs by governments, businesses, and organizations in most countries. The SDGs set out a vision for a better world that relies on cooperation and interdependence [6].

The 17 SDGs, shown in Figure 1, were formally adopted by all 193 member states of the UN in 2015; they aim to end extreme poverty, protect the planet, and ensure prosperity for all by 2030 [7].
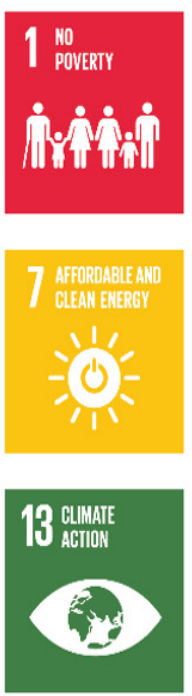
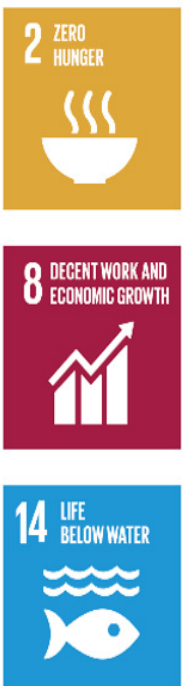
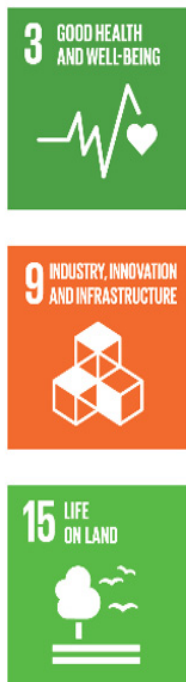
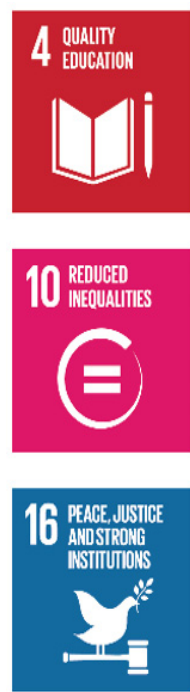
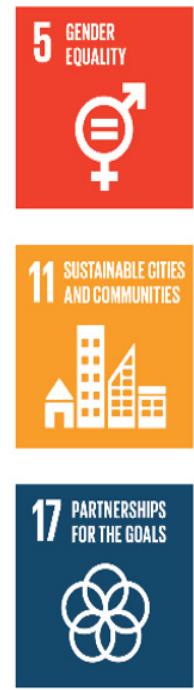
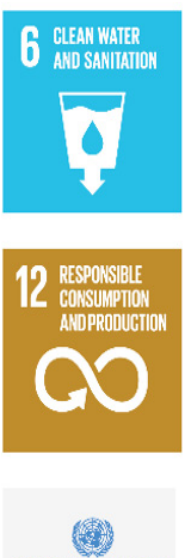

SUSTAINABLE DEVELOPMENT GALS

Figure 1. The 17 Sustainable Development Goals (SDGs).

The SDGs continue the work of the Millennium Development Goals (MDGs), which drove global action to address the basic needs of the world's poorest countries from 2000 to 2015. However, the SDGs differ from the MDGs in several significant ways that make them far more influential and consequential [8]. First, the SDGs cover a much broader range of challenges than the MDGs, most of which are relevant and applicable to all countries. Second, they emphasize the interlinkages between the social, economic, and environmental dimensions of sustainable development, as well as between the 
goals themselves. Third, they include targets focused on mobilizing the means required to implement the SDGs, such as partnerships, financing, and enabling policies. Fourth, they were developed through the largest international consultation ever with a wide range of stakeholders, including governments, non-governmental organizations (NGOs), and importantly, the business sector. Fortunately, there is a growing recognition that sustainability is a global issue which requires a global response. Hence, all groups need to be actively engaged in achieving the SDGs at the local, national, regional, and international levels [9]. In other words, it is now recognized that sustainable development represents a great challenge that is everyone's responsibility, and there is an explicit call to attention for the business sector, civil society, governments, academia, among other stakeholders, requiring their collaboration.

Although the SDGs are not legally binding, they are expected to leverage more support because they are the result of extensive and inclusive global negotiation and dialogue that also involved middleand low-income countries. In addition, both the private sector and civil society are expected to be far more engaged in the SDGs. Therefore, they will probably be major influencers on the strategies and actions of governments, businesses, and organizations, as well as the development of financial flows over the next 15 years. After all, "Agenda 2030 and the SDGs are becoming accepted as forming a key element of the doxa of the field, the unspoken rules of the game" [10] (p. 95).

\section{The Role of Higher Education Institutions}

Different authors argue that the United Nations (UN) has put education at the heart of its sustainable development strategy acknowledging that educators and business leaders can influence how future generations think and act $[10,11]$. In fact, according to the Sustainable Development Solutions Network [12], education and research are explicitly recognized in a number of the SDGs and universities have a direct role in addressing these.

The educational system has long been the appropriate context to promote sustainable development because it may influence students' worldviews and attitudes towards sustainability and contribute to more profound social change [13]. Education is able to 'produce' certain kinds of people-those that meet societal needs [10]. In this regard, one of the most important roles of the universities in this new context is creating current and future 'SDGs implementers'. Furthermore, "any meaningful and lasting change in the conduct of corporations toward sustainability must involve the institutions that most directly act as drivers of business behavior, especially academia [14] (p. 3). Academic institutions help shape the attitudes and behavior of business leaders through education, research, training, and other pervasive, but less tangible, activities, such as the spread and advocacy of new values and ideas. Through these means, academic institutions have the potential to generate a wave of positive change, thereby helping to ensure a world where both enterprises and societies can flourish". Thus, education becomes of critical importance in the path towards sustainability $[2,5,15]$. SDGs cannot be achieved without their proper embedment in the educational system (across disciplines and levels).

The contribution of universities to the SDGs can be rather broad. Universities could support the implementation of every single SDG as well as maintain an ongoing commitment to the SDG framework. Concretely, universities can contribute to SDGs through education, research, innovation, and also external leadership (see Table 1). Some of these main areas of contribution are: (1) providing students with the knowledge, skills, and motivation to understand and address the SDGs and mobilizing them towards that direction (educational level); (2) providing new knowledge, technology, new ways of doing things, that is, SDGs solutions (research and knowledge transfer level); (3) implementing the principles of SDGs within their own governance, operations, and culture (operational level); (4) providing cross-sectoral leadership and implementation by guiding/participating in the dialogue for taking action (social level). This latter level is probably the most strategic given its transcendence to a broader array of sectors and countries, but also the most difficult since it is expected to generate various points of contestation and critique [16,17]. 
Table 1. The incorporation of SDGs in higher education.

\begin{tabular}{|c|c|c|c|c|}
\hline SDGs & Universities & & & \\
\hline & Educational level & $\begin{array}{l}\text { Research and knowledge } \\
\text { transfer level }\end{array}$ & Operational level & Social level \\
\hline
\end{tabular}

Without any doubt, addressing SDGs will require transformations in how societies and economies function, suggesting new modes of production and consumption. Throughout this process universities can make important contributions. Particular disciplines such as geology [18] have already started to evaluate how they can contribute to the completion of specific SDGs. Recognizing the potential areas of contribution is the first step prior to engaging in a larger societal debate regarding the specific actions to be taken. Other authors [19] have gone a step further discussing future sustainability scenarios for universities by painting a portrait of socially-, environmentally-, and economically-oriented universities, all of them pursuing different SDGs. Socially-oriented universities would place more focus on issues such as gender equality, food security, and nutrition and health. Environmentally-oriented universities are explicitly oriented towards the issues of waste, sustainable agriculture, and climate change, among others. Finally, the economic focus refers to poverty eradication, the promotion of a green economy, and sustainable consumption and production cycles.

\section{SDG and Management Education: Push or Pull?}

Although a wide range of stakeholders (governments, NGOs, academia, citizens, etc.) are key agents in advancing the SDGs, it is the business sector that will be instrumental in the success of the individual targets, through the way companies operate, their innovation, and collaboration with other agents and through the development of new business models [9].

When we think about companies as citizens of the community, they, like people, have certain duties and responsibilities they must fulfill to be perceived as legitimate and accepted [20]. In this regard, contributing to the completion of the SDGs will be one of those ideas that, in words of Professor Carroll, no one would rightly oppose. As previously mentioned, the primary advantages of the SDGs are that they tend to stress the long-term perspective when discussing economic development; they encompass economic, social, and environmental factors, while focusing on the world's most pressing challenges, including ending poverty and bringing economic prosperity, social inclusion, environmental sustainability, and peace to all people. Companies have increasingly adopted the framework of ECSRS and in turn, this business acceptance leads to their progressive institutionalization within society [20]. SDG-related practices are becoming more commonplace, more formalized, varied, and deeply integrated into business practices. At the same time, this process of institutionalization reveals to business managers how SDGs and profits can be strategically reconciled. The successful implementation of the SDGs could strengthen the enabling environment for doing business, minimizing risks while also providing a myriad of new opportunities [21]. As the CEO of Unilever, Paul Polman stated, "There is no business case for enduring poverty. We have the opportunity to unlock trillions of dollars through new markets, investments and innovation. But to do so, we must challenge our current practices and address poverty, inequality and environmental challenges. Every business will benefit from operating in a more equitable, resilient world if we achieve the SDGs." [9] (p. 84).

In addition, the SDGs framework is relevant and applicable to all countries. Globalization requires managers to face challenges in a global context and adequately respond to social issues in host nations. 
Thus, the 17 SDGs can be seen as a common framework and template for understanding sustainable development in both developed and developing countries.

Hence, what is suggested here is that the SDGs are increasingly becoming the framework adopted to manage the social contract between the business sector and society. SDGs are becoming the common language for the interaction of companies with other stakeholders to contribute to a better world.

Yet as more businesses embed the SDGs as a prime strategic focus, the demand for management or business graduates who understand and can implement the SDG agenda will also grow. Thus, management education should respond to the increased demand for SDG-oriented education. In other words, the integration of SDGs in management education does not necessarily reflect a proactive approach on the part of universities. Certainly, on one hand, business schools need to incorporate SDGs and prepare future business leaders and managers for a better and more sustainable future [11,22]; but, on the other hand, companies also expect them to do so [23]. Furthermore, different global stakeholders related to management education have embraced the SDGs and explicitly asked universities to do the same. For instance, examples of international accreditation bodies for business schools or networks include the Global Business School Network and the Environmental Association for Universities and Colleges $[10,24]$.

There is already research evidencing an effort by universities in various countries, like Italy [25], the UK [26], or Spain [27], to integrate SDGs in management education [24,28]. However, there are still debates regarding the place of business education in this new sustainable development agenda [10]. It has been suggested that business schools should review their educational programs and curricula in line with the SDGs. However, there is no single strategy in designing business curricula to include SDGs [1]. For instance, the following issues should be decided: concentration on specific subjects or dispersion (stand-alone versus embedded subjects); single discipline versus multidisciplinary approaches; obligatory versus elective courses; distribution within university degrees.

A faster and more organic strategy to integrate SDGs in management education would be to first evaluate what subjects in management education are already focusing on topics that have the same purpose as SDGs in wishing to change the world for the better. In this regard, subjects which focus on business-and-society relationships are excellent candidates for integrating in a natural way the SDGs in management education. The essence of business-and-society or business-in-society relationships has been captured in management education by different, but complementary and related, frameworks including corporate social responsibility (CSR), business ethics (BE), stakeholder management (SM), corporate citizenship (CC), and sustainability (SUS) [20]. Subjects on any of the aforementioned topics have already been introduced for bachelor and postgraduate degrees in management [1]; thus, they could be used as 'entry points' for introduction of the SDGs.

Although differences among these frameworks have been previously argued [29], business practitioners and the business press tend to use them as synonyms with slight distinct nuances. It is easy to see how these five different frameworks-corporate social responsibility, business ethics, stakeholder management, sustainability, and corporate citizenship-have so much in common that they often are used interchangeably by business organizations and managers [20]. In fact, previous experience has demonstrated that executives latch onto a term that seems to be in vogue and from time-to-time employ new language terms and frameworks to always appear on the cutting edge. As Professor Carroll suggested, "doubtless this trend will continue and other concepts will arrive on the scene and compete for popularity [20] (p. 93). Whether they will ever be sufficiently distinct from CSR remains to be seen. Today, CSR, Sustainability and Corporate Citizenship seem to have the most in common and are most frequently used by companies, but other ideas and frameworks are always coming along serving as complementary or competing notions those in this field are tempted to grasp upon". Taking all these into account, SDGs can also be seen as a new language to be used by companies and taught by business schools.

Therefore, this new SDG lexicon should be first included in subjects in the fields of business ethics, CSR, and sustainability and then in more traditional business subjects. Business schools need to ensure 
that the curricula ensure a full awareness of the SDGs and their potential impact in different areas of activity. SDGs should be broadly represented in the academic competences of the curricula [27], but a more specific plan of introduction for SDGs across business courses should also be established. An example is provided by Storey and colleagues [10] using the first SDG: "End poverty in all its forms everywhere". This goal, as they discuss, requires different business actions to be taken, such as ensuring fair pay, fair labor standards, responsible marketing, and fair pricing, to name a few. In order for business graduates to get a better grasp on how their future business decisions could positively achieve this goal, the authors suggest that the aforementioned issues should be incorporated across different existing core business subjects (e.g., responsible marketing and fair pricing in marketing while fair pay in human resources subjects), and also in specific business ethics and sustainability courses. Other authors indicate that the goal of poverty eradication should also focus on four main areas: big business and poverty reduction; viewing the poor as markets; lending to the poor; and entrepreneurship and poverty [28]. Furthermore, the adequacy of different learning and assessment strategies should be evaluated in the context of each particular course and degree [27].

Furthermore, business students could get an even better grasp of the implications of organizational decision making if an interdisciplinary approach is employed. Previous research has argued in favor of interdisciplinarity [30,31] since the issues we deal with, such as poverty, human rights, or climate change, cannot be addressed by single disciplines or sectors. In a similar vein with Gill [18], business schools first need to explore the interconnectedness between SDGs and management, and then look for areas of collaboration with other disciplines, particularly the sciences. Fostering greater interdisciplinarity between management and other disciplines could also contribute in closing the "gap between what sciences produces to inform humanity" and policy and business decision making [32] (p. 552).

\section{Conclusions}

Introducing ECSRS in management education has been, and still is, a key step to render business schools accountable in their responsibility towards the society. The integration of SDGs in management education is a further step towards that direction. Business schools have a quadruple function in doing so:

(i) as responsible educators that help students understand complex challenges faced by businesses and societies and provide them with the skills, values, and knowledge related to the achievement of the SDGs;

(ii) as responsible knowledge creators that are concerned with the social implications of their research outputs while ensuring that the knowledge generated is also useful for different stakeholders and visible;

(iii)as sustainable organizations that control their own social and environmental impact;

(iv) as key stakeholders who actively participate in the societal dialogue taking place for any of the issues covered by the SDGs.

Therefore, this Special Issue not only offers rich insights on the state of ECSRS in management education, but also invites further reflection on how management education can contribute to achieve SDGs. In order to make sustainable development a reality and change the world for the better, SDGs need to become the cornerstone for management education. Gradually, the curriculum content of all management courses should be reviewed through the lens of SDGs. Every year hundreds of thousands of students graduate from business schools internationally, both from degree and non-degree programs [9]. These students then go on to lead and influence virtually every type of organization, and each and every one of them has the opportunity to impact what our future will, or will not, look like. If organizations slowly fill up with individuals who apply the triple bottom line and actively engage with the SDGs in how they do business, this would enable us to move forward with sustainability goals in a timely, as well as mutually beneficial, way. 
Certainly, it is naïve to think that the promotion of SDGs will be without challenges. Others have already pointed out some of them [26]: lack of acceptance on the part of some students, complex translation of SDGs into curricula, difficulty in dealing with all the goals, and most importantly a limited timeframe. At the same time, young generations demonstrate a higher sensitivity towards climate change and sustainability as evidenced in the globalized Fridays for Future movement. On an optimistic note, we cannot forget that "universities have access to large concentrations of young people who are passionate, creative and have a desire for a better world" [12] (p. 8). Universities have to make the maximum effort for the successful implementation of the new global sustainable development agenda, because, hopefully, when we change the way employees, managers, CEOs, and leaders think and act, this will lead to broader changes across industries around the world [33]. The SDGs' framework emphasizes the need to take action in a collaborative and urgent manner. In management education, SDGs should be understood as an opportunity to accelerate the long required changes in management curricula in order to give sustainable development the protagonism it deserves.

Author Contributions: D.S.-P. and E.P. equally participated in the elaboration of this manuscript, including the original draft preparation and the editing that followed. All authors have read and agreed to the published version of the manuscript.

Funding: This research received no external funding.

Conflicts of Interest: The authors declare no conflict of interest.

\section{References}

1. Setó-Pamies, D.; Papaoikonomou, E. A Multi-level Perspective for the Integration of Ethics, Corporate Social Responsibility and Sustainability (ECSRS) in Management Education. J. Bus. Ethics 2016, 136, 523-538.

2. Sherman, P.; Hansen, J. The new corporate social responsibility: A call for sustainability in business education. Int. J. Environ. Sustain. Dev. 2010, 9, 241-254. [CrossRef]

3. Matten, D.; Moon, J. Corporate social responsibility education in Europe. J. Bus. Ethics 2004, 54, $323-337$. [CrossRef]

4. Moon, J.; Orlitzky, M. Corporate social responsibility and sustainability education: A trans-Atlantic comparison. J. Manag. Organ. 2011, 17, 583-603. [CrossRef]

5. Tilbury, D. Are we learning to change? Mapping global progress in education for sustainable development in the lead up to 'Rio Plus 20'. Glob. Environ. Res. 2011, 14, 101-107.

6. Owen, T.L. Higher education in the sustainable development goals framework. Eur. J. Educ. 2017, 52, 399-562. [CrossRef]

7. United Nations (UN) General Assembly. Transforming Our World: The 2030 Agenda for Sustainable Development; Resolution Adopted by the General Assembly A/RES/70/1. 2015. Available online: www. refworld.org/docid/57b6e3e44.html (accessed on 3 August 2017).

8. Caprani, L. Five ways the sustainable development goals are better than the millennium development goals and why every educationalist should care. Manag. Educ. 2016, 30, 102-104. [CrossRef]

9. Weybrecht, G. From challenge to opportunity-Management education's crucial role in sustainability and the Sustainable Development Goals-An overview and framework. Int. J. Manag. Educ. 2017, 15, 84-92. [CrossRef]

10. Storey, M.; Killian, S.; O'Regan, P. Responsible management education: Mapping the field in the context of the SDGs. Int. J. Manag. Educ. 2017, 15, 93-103. [CrossRef]

11. Avelar, A.B.A.; Oliveira, K.D.S.; Pereira, R.S. Education for advancing the implementation of the Sustainable Development Goals: A systematic approach. Int. J. Manag. Educ. 2019, 17, 100322. [CrossRef]

12. SDSN Australia/Pacific. Getting Started with the SDGs in Universities: A Guide for Universities, Higher Education Institutions, and the Academic Sector; Sustainable Development Solutions Network: Melbourne, Australia, 2017.

13. Dobson, A. Environmental citizenship: Towards sustainable development. Sustain. Dev. 2007, 15, $276-285$. [CrossRef]

14. United Nations Global Compact. Principles for Responsible Management Education. Available online: http://www.unglobalcompact.org/docs/news_events/8.1/PRME.pdf (accessed on 25 September 2007).

15. Felton, E.L.; Sims, R.R. Teaching business ethics: Targeted outputs. J. Bus. Ethics 2005, 60, 377-391. [CrossRef] 
16. Bebbington, J.; Unerman, J. Achieving the United Nations Sustainable Development Goals: An enabling role for accounting research. Account. Audit. Account. J. 2018, 31, 2-24. [CrossRef]

17. Griggs, D.J.; Nilsson, M.; Stevance, A.; McCollum, D. A Guide to SDG Interactions: From Science to Implementation; International Council for Science: Paris, France, 2017.

18. Gill, J.C. Geology and the Sustainable Development Goals. Episodes 2017, 40, 70-76. [CrossRef]

19. Beynaghi, A.; Trencher, G.; Moztarzadeh, F.; Mozafari, M.; Maknoon, M.; Leal Filho, W. Future sustainability scenarios for universities: Moving beyond the United Nations Decade of Education for Sustainable Development. J. Clean. Prod. 2016, 112, 3464-3478. [CrossRef]

20. Carroll, A.B. Corporate social responsibility: The centerpiece of competing and complementary frameworks. Organ. Dyn. 2015, 44, 87-96. [CrossRef]

21. Weybrecht, G. Management Education and the Sustainable Development Goals-Get Engaged. 2015. Available online: http://www.aacsb.edu/blog/2015/october/management-education-and-the-sustainable-developmentgoals-get-engaged (accessed on 14 August 2017).

22. Vasilescu, R.; Barna, C.; Epure, M.; Baicu, C. Developing university social responsibility: A model for the challenges of the new civil society. Procd. Soc. Behav. Sci. 2010, 2, 4177-4182. [CrossRef]

23. Adams, C.A. The role of leadership and governance in transformational change towards sustainability. Glob. Responsib. 2013, 9, 9-12.

24. Miotto, G.; López, M.P.; Rodríguez, J.R. Gender Equality and UN Sustainable Development Goals: Priorities and Correlations in the Top Business Schools' Communication and Legitimation Strategies. Sustainability 2019, 11, 302. [CrossRef]

25. Mion, G.; Broglia, A.; Bonfanti, A. Do Codes of Ethics Reveal a University's Commitment to Sustainable Development? Evidence from Italy. Sustainability 2019, 11, 1134. [CrossRef]

26. Ndubuka, N.; Rey-Marmonier, E. Capability approach for realising the Sustainable Development Goals through Responsible Management Education: The case of UK business school academics. Int. J. Manag. Educ. 2019, 17, 100319. [CrossRef]

27. Tejedor, G.; Segalàs, J.; Barrón, A.; Fernández-Morilla, M.; Fuertes, M.T.; Ruiz-Morales, J.; Gutiérrez, I.; García-González, E.; Aramburuzabala, P.; Hernández, A. Didactic Strategies to Promote Competencies in Sustainability. Sustainability 2019, 11, 2086. [CrossRef]

28. Neal, M. Learning From Poverty: Why Business Schools Should Address Poverty, and How They Can Go About It. Acad. Manag. Learn. Educ. 2017, 16, 54-69. [CrossRef]

29. Garavan, T.N.; McGuirre, D. Development and Society: Human Resource Development's Role in Embedding Corporate Social Responsibility, Sustainability, and Ethics in Organizations. Adv. Dev. Hum. Res. 2010, 12, 487-507. [CrossRef]

30. Annan-Diab, F.; Molinari, C. Interdisciplinarity: Practical approach to advancing education for sustainability and for the Sustainable Development Goals. Int. J. Manag. Educ. 2017, 15, 73-83. [CrossRef]

31. Luppi, E. Training to education for sustainable development through e-learning. Proc. Soc. Behav. Sci. 2011, 15, 3244-3251. [CrossRef]

32. Mukhi, U.; Quental, C. Exploring the challenges and opportunities of the United Nations sustainable development goals: A dialogue between a climate scientist and management scholars. Corp. Gov. 2019, 19, 552-564. [CrossRef]

33. Weybrecht, G. Grassroots: The sustainable MBA. EFMD Glob. Focus 2010, 4, 26-29.

(C) 2020 by the authors. Licensee MDPI, Basel, Switzerland. This article is an open access article distributed under the terms and conditions of the Creative Commons Attribution (CC BY) license (http://creativecommons.org/licenses/by/4.0/). 